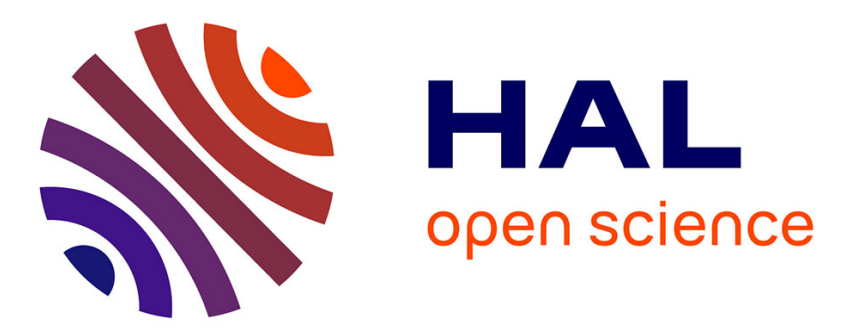

\title{
Revealing the structural origin of the redox-Bohr effect: the first solution structure of a cytochrome from Geobacter sulfurreducens
}

Leonor Morgado, Vítor B. Paixão, Marianne Schiffer, P Raj Pokkuluri, Marta Bruix, Carlos A. Salgueiro

\section{To cite this version:}

Leonor Morgado, Vítor B. Paixão, Marianne Schiffer, P Raj Pokkuluri, Marta Bruix, et al.. Revealing the structural origin of the redox-Bohr effect: the first solution structure of a cytochrome from Geobacter sulfurreducens. Biochemical Journal, 2011, 441 (1), pp.179-187. 10.1042/BJ20111103 . hal-00658161

\section{HAL Id: hal-00658161 \\ https://hal.science/hal-00658161}

Submitted on 10 Jan 2012

HAL is a multi-disciplinary open access archive for the deposit and dissemination of scientific research documents, whether they are published or not. The documents may come from teaching and research institutions in France or abroad, or from public or private research centers.
L'archive ouverte pluridisciplinaire HAL, est destinée au dépôt et à la diffusion de documents scientifiques de niveau recherche, publiés ou non, émanant des établissements d'enseignement et de recherche français ou étrangers, des laboratoires publics ou privés. 


\section{Revealing the structural origin of the redox-Bohr effect: the first solution structure of a cytochrome from Geobacter sulfurreducens}

Leonor Morgado*, Vitor B. Paixão†, Marianne Schifferł, P. Raj Pokkulurił, Marta Bruix§ ${ }^{1}$, Carlos A. Salgueiro ${ }^{* 1}$

* Requimte-CQFB, Departamento de Química, Faculdade de Ciências e Tecnologia, Universidade Nova de Lisboa, Campus Caparica, 2829-516 Caparica, Portugal

† Instituto de Tecnologia Química e Biológica, Universidade Nova de Lisboa, Rua da Quinta Grande 6, 2780-156 Oeiras, Portugal

‡ Biosciences Division, Argonne National Laboratory, Argonne, Illinois 60439, USA

$\S$ Departamento de Química Física Biológica, Instituto de Química-Física "Rocasolano", CSIC, Serrano 119, 28006 Madrid, Spain

${ }^{1}$ Corresponding authors: mbruix@iqfr.csic.es and csalgueiro@dq.fct.unl.pt 


\section{SYNOPSIS}

Geobacter sulfurreducens (Gs) can transfer electrons to the exterior of its cells, a property that makes it a preferential candidate for the development of biotechnological applications. Its genome encodes for over one hundred cytochromes and despite their abundance and key functional roles, to date there is no structural information for these proteins in solution. The trihaem cytochrome PpcA has a crucial role in the conversion of electronic energy into proton motive force, a fundamental step for ATP synthesis in the presence of extracellular electron acceptors. In this work, ${ }^{15} \mathrm{~N}$-labelled PpcA was produced and NMR spectroscopy was used to determine its solution structure in the fully reduced state, its backbone dynamics and the $\mathrm{pH}$-dependent conformational changes. The structure obtained is well defined, with an average pairwise root-mean-square deviation of $0.25 \AA$ for the backbone atoms and $0.99 \AA$ for all heavy atoms, and constitutes the first solution structure of a Gs cytochrome. The redox-Bohr centre responsible for controlling the electron/proton transfer was identified, as well as the putative interacting regions between PpcA and its redox partners. The solution structure of PpcA will constitute the foundation for studies aimed at mapping out in detail these interacting regions.

Heading title: PpcA solution structure

Keywords: Multihaem cytochromes, Redox proteins, NMR, Geobacter, structure-function relationship

Abbreviations: PpcA - Geobacter sulfurreducens trihaem cytochrome encoded by gene GSU0612, $\mathrm{GsC}_{7}$ - Geobacter sulfurreducens trihaem cytochromes, rmsd - root-mean-square deviation. 


\section{INTRODUCTION}

The bacterium Geobacter sulfurreducens (Gs) is able to reduce extracellular radioactive and toxic metal ions, as well as transfer electrons to electrode surfaces. These properties make this microorganism an important candidate for developing biotechnological applications in bioremediation and microbial electricity production $[1,2]$. The genome of $G s$ was fully sequenced and encodes for $111 c$-type cytochromes, of which 73 are multihaemic [3]. Among these, a family composed by five periplasmic trihaem cytochromes $c_{7}$ has been identified. These cytochromes contain approximately 70 amino acids, three haem groups with bis-histidinyl axial coordination, and share between 41 and $77 \%$ sequence identities. They were designated as PpcA (encoded by gene GSU0612), PpcB (GSU0364), PpcC (GSU0365), PpcD (GSU1024) and PpcE (GSU1760) [4]. Genomic and proteomic studies showed that these proteins affect differently the extracellular reduction of iron and uranium by Gs $[5$, 6].

The trihaem cytochrome PpcA is involved in extracellular metal ion reduction in vivo, and in vitro studies showed that it displays $\mathrm{Fe}^{\mathrm{III}}$ reductase activity [7]. The detailed thermodynamic properties of PpcA redox centres have been determined, showing that the haem groups have negative reduction potentials, which are modulated by haem-haem redox interactions and by redox-Bohr interactions [8]. The functional rationalization of these properties at physiological $\mathrm{pH}$ showed that $\mathrm{PpcA}$ can couple electron and proton transfer. Thus, PpcA might contribute to the proton electrochemical potential gradient across the periplasmic membrane that drives ATP synthesis, constituting an additional mechanism to sustain cellular growth in presence of extracellular electron acceptors [9]. Given the importance of PpcA on metal ions respiration, understanding the function of this protein is required for the study of the biogeochemical activities of this bacterium. Studies of this type could lead to design of improved biotechnological applications based on Gs metabolic activities.

The modulation of multihaem cytochromes reduction potentials by redox and redox-Bohr interactions requires control of both redox state and the protonation state of the protein. Within this scope, structure determination of the protein in solution is the preferred method. The crystal structure of PpcA was previously determined [4]. However, in contrast to the structures obtained for the other four Gs cytochromes $C_{7}\left(G_{\left.S C_{7}\right)}\right)$, PpcA crystals could only be obtained in the presence of the additive deoxycholate [4]. Preliminary NMR studies carried out for PpcA samples without deoxycholate showed that the haem core architecture in solution is different from the PpcA crystal structure, but is similar to that observed in the crystal structures of the other four $\operatorname{Gsc}_{7}[10,11]$. These studies showed that the binding of deoxycholate to PpcA in the crystals altered its structure [11]. Attempts to crystallize PpcA in absence of deoxycholate were unsuccessful and, thus, the structural information for this protein in an unaltered form is not available.

In this work, we used our recent developed methodology to obtain isotopically labelled recombinant multihaem cytochromes to produce ${ }^{15} \mathrm{~N}$-labelled PpcA in a cost-effective manner [12]. The yields obtained were sufficient to determine its high-resolution solution structure. The structure presented is the first solution structure reported for a cytochrome from Gs. The structural information obtained was used to explore the backbone dynamics and to fingerprint the residues involved in the redox-Bohr effect, a crucial property that allows PpcA to couple electron and proton transfer at physiological $\mathrm{pH}$. 


\section{EXPERIMENTAL}

\section{Bacterial growth and protein purification}

Uniformly ${ }^{15} \mathrm{~N}$ labelled and unlabelled PpcA were expressed in Escherichia coli as previously described [12]. Briefly, PpcA was expressed in plasmid pCK32 in E. coli BL21(DE3) by coexpression with plasmid $\mathrm{pEC} 86$ that encodes for the cytochrome $c$ maturation gene cluster [13]. After reaching an $\mathrm{OD}_{600}$ of $\sim 1.5$ cultures were processed in either of two ways: (a) addition of $10 \mu \mathrm{M}$ isopropyl $\beta$-D-thiogalactoside (IPTG) and growing overnight at $30{ }^{\circ} \mathrm{C}$ to express unlabelled protein, followed by harvesting by centrifugation; (b) cells were collected by centrifugation after reaching an $\mathrm{OD}_{600}$ of 1.0, washed twice with $250 \mathrm{ml} \mathrm{M} 9$ medium, resuspended in minimal media (in a ratio of 250 $\mathrm{ml}$ of minimal medium for each litre of $2 \mathrm{xYT}$ medium) supplied with $1 \mathrm{~g} / \mathrm{l}^{15} \mathrm{NH}_{4} \mathrm{Cl}$ as nitrogen source (together with $1 \mathrm{mM}$ of the haem precursor $\alpha$-aminolevulinic acid, trace amounts of metal ion salts, biotin and thiamine), grown overnight at $30{ }^{\circ} \mathrm{C}$ in the presence of $0.8 \mathrm{mM}$ IPTG and harvested by centrifugation. Isolation of the periplasmic fraction and purification of the protein was done as previously described $[12,14]$.

\section{NMR sample preparation}

For NMR experiments, samples were lyophilized and dissolved in $45 \mathrm{mM}$ sodium phosphate buffer (100 mM ionic strength) $\mathrm{pH} 7.1$ (direct reading with a glass micro electrode without correction for isotope effects) and with $0.04 \%$ sodium azide to avoid bacterial growth. ${ }^{15} \mathrm{~N}$ labelled sample was prepared in $92 \% \mathrm{H}_{2} \mathrm{O} / 8 \% \mathrm{D}_{2} \mathrm{O}$ and unlabelled samples prepared in $92 \% \mathrm{H}_{2} \mathrm{O} / 8 \% \mathrm{D}_{2} \mathrm{O}$ or in pure $\mathrm{D}_{2} \mathrm{O}$. Final protein concentration was about $1 \mathrm{mM}$. In order to avoid oxidation of the samples, the NMR tubes were sealed with a gas-tight serum cap and the air was flushed out form the sample. The samples were then reduced directly in the NMR tube with gaseous hydrogen in the presence of catalytic amounts of hydrogenase from Desulfovibrio vulgaris (Hildenborough), as previously described [10].

\section{NMR spectroscopy}

NMR experiments were acquired on a Bruker Avance $800 \mathrm{MHz}$ or on a BrukerAvance $600 \mathrm{MHz}$ spectrometers equipped with triple-resonance cryoprobes. All experiments were acquired at $298 \mathrm{~K}$ and ${ }^{1} \mathrm{H}$ and ${ }^{15} \mathrm{~N}$ chemical shifts were respectively calibrated using the water signal as internal reference and through indirect referencing [15]. Spectra were processed using TOPSPIN (BrukerBiospin, Karlsruhe, Germany) and analyzed with Sparky [16]. The following set of experiments was acquired: ${ }^{15} \mathrm{~N}$ labelled sample: $2 \mathrm{D}-{ }^{1} \mathrm{H}-{ }^{15} \mathrm{~N}-\mathrm{HSQC}, 3 \mathrm{D}-{ }^{1} \mathrm{H}-{ }^{15} \mathrm{~N}$-TOCSY $(60 \mathrm{~ms})$ and $3 \mathrm{D}-{ }^{1} \mathrm{H}-{ }^{15} \mathrm{~N}-\mathrm{NOESY}(80 \mathrm{~ms})$; unlabelled sample in $92 \% \mathrm{H}_{2} \mathrm{O} / 8 \% \mathrm{D}_{2} \mathrm{O}: 2 \mathrm{D}-{ }^{1} \mathrm{H}-\mathrm{COSY}, 2 \mathrm{D}-{ }^{1} \mathrm{H}-\mathrm{TOCSY}(60 \mathrm{~ms})$ and $2 \mathrm{D}-{ }^{1} \mathrm{H}-\mathrm{NOESY}$ $(50 \mathrm{~ms})$; unlabelled sample in $\mathrm{D}_{2} \mathrm{O}: 2 \mathrm{D}-{ }^{1} \mathrm{H}-\mathrm{COSY}, 2 \mathrm{D}-{ }^{1} \mathrm{H}-\mathrm{TOCSY}(45 \mathrm{~ms})$ and $2 \mathrm{D}-{ }^{1} \mathrm{H}-\mathrm{NOESY}(100$ $\mathrm{ms}) .1 \mathrm{D}-{ }^{1} \mathrm{H}$ NMR spectra were obtained before and after each multidimensional spectrum to confirm protein integrity and fully reduction.

A series of ${ }^{1} \mathrm{H}-{ }^{15} \mathrm{~N}$ correlation spectra were measured at $800 \mathrm{MHz}$ and at $600 \mathrm{MHz}$ to obtain the ${ }^{15} \mathrm{~N}$ longitudinal $\left(T_{1}\right)$ and transverse $\left(T_{2}\right)$ relaxation times in the same conditions used for structure calculation. For the longitudinal relaxation rate, a set of eight experiments was acquired with relaxation delays from 5 to $1200 \mathrm{~ms}$, and for the transverse relaxation rate, eight experiments were recorded with relaxation delays between 16 to 130 ms. Heteronuclear ${ }^{15} \mathrm{~N}\left\{{ }^{1} \mathrm{H}\right\}$ NOE were determined from the ratio of two experiments with and without saturation. Data from the different spectra were treated as peak heights.

The effect of $\mathrm{pH}$ titration on the chemical shifts was determined by analyzing a series of $2 \mathrm{D}-{ }^{1} \mathrm{H}-{ }^{15} \mathrm{~N}-$ HSQC spectra acquired in the $\mathrm{pH}$ range 5.5 to 9.5 . The $\mathrm{pH}$ of the sample was adjusted by addition of small amounts of $\mathrm{NaOD}$ or DCl inside an anaerobic chamber (MBraun LABstar) to avoid sample oxidation. The weighted average chemical shift $\left(\Delta \delta_{\text {avg }}\right)$ of each backbone and side chain amide was calculated as: $\Delta \delta_{\text {avg }}=\sqrt{ }\left[\left(\Delta \delta^{2} \mathrm{~N} / 25+\Delta \delta^{2} \mathrm{H}\right) / 2\right]$, where $\Delta \delta \mathrm{H}$ and $\Delta \delta \mathrm{N}$ are the differences in the ${ }^{1} \mathrm{H}$ and ${ }^{15} \mathrm{~N}$ chemical shifts, respectively [17].

\section{Assignment and determination of restraints}

Protein assignment, including backbone, side chain and haem resonances, was previously described [18] and data was deposited in the BioMagResBank (http://www.bmrb.wisc.edu) under BMRB 
accession number 16842 . For structure determination, the cross-peaks assigned in the $50 \mathrm{~ms} 2 \mathrm{D}-{ }^{1} \mathrm{H}$ NOESY were integrated using the program Sparky. A Gaussian function was used for the integration of isolated peaks and sum data in a box surrounding the peak for overlapped ones. Cross-peaks due to protons separated by fixed distances and all intra-haem cross-peaks, except those involving the propionate groups, were not included. Volume for integrated cross-peaks were converted into volume restraints and used as input for the program PARADYANA [19], as described previously [20]. Initial structures were calculated with a preliminary set of NOE data and the resulting conformers were then analyzed and used to assign additional peaks in the NOESY spectra. The program GLOMSA [21] was used for stereospecific assignment during the process of structure calculation. Three non-standard residues were used for structure calculations: fast-flipping aromatic residues with pseudo-atoms to limit the orientations of the planes, flexible haem groups and proline residues with fixed upper limit distances for ring closure. A set of 69 fixed upper limit distances associated with this type of residues was also used as input for PARADYANA. In the final stages of structure refinement, the calculated structures were checked for short (less than $2.5 \AA$ ) distances between assigned protons that should give rise to significant NOEs.

\section{Structure calculation and analysis}

Structure calculation was performed with the program PARADYANA, a version of DYANA that takes peak volumes as input and pseudocontact shifts in the case of paramagnetic proteins [19]. In each calculation 200 conformers were determined, from which the 10 structures with lowest target function value were selected for further analysis. In the final calculation, 400 conformers were determined and the 20 with lowest target function value were selected. The program CHIMERA [22] was used for visual analysis during preliminary calculations and the program MOLMOL [23] was used for superimposition and identification of elements of secondary structure in the final set of conformers. Quality of the structures was analysed with PROCHECK-NMR [24].

\section{Data Bank accession number}

The structure of PpcA has been deposited in the Protein Data Bank with accession number 2LDO. 


\title{
RESULTS
}

\begin{abstract}
${ }^{15} \mathrm{~N}$-labelled PpcA was produced as previously described [12] with a final yield of $4 \mathrm{mg}$ of pure protein per litre of culture. We used the expression system developed by Londer and co-workers [14], which uses the lac promoter in the expression plasmid with co-expression of the cytochrome $c$ maturation gene cluster on a separate plasmid. The use of this system allows obtaining high protein yields with the correct fold and post-translational modification of the haem groups in a cost-effective manner and, concomitantly to overcome the traditional difficulties associated with the determination of solution structures using natural abundance samples of multihaem proteins.
\end{abstract}

\section{Sequential assignment and structure calculations}

PpcA has a MW of $9.57 \mathrm{kDa}$, and contains three low spin $c$-type haem groups with bis-histidinyl axial coordination and an unusually high content of lysine residues (24\%). The haems are numbered I, III and IV, a designation that derives from the superimposition of the haems in cytochromes $c_{7}$ with those of the structurally homologous tetrahaem cytochromes $c_{3}$. The assignment of all haem protons, the protein backbone and side chains resonances, except for the first two residues, was previously reported [18]. The 60 haem proton signals (20 per haem) were unambiguously assigned, according to the strategy described by Turner and co-workers [25]. After that, individual spin-systems were first identified according to their type and then sequence-specific assignment made. A summary of the sequential connectivities between $\mathrm{NH}, \mathrm{H} \alpha$ and $\mathrm{H} \beta$ protons is shown in supplementary Figure $\mathrm{S} 1$. The total extent of the assignment is $93 \%$, excluding carboxyl, amino and hydroxyl groups.

Assigned cross-peaks in the $\mathrm{H}_{2} \mathrm{O}$ spectra were integrated and converted into volume restraints, resulting in 1115 lower limits for volumes (lov) and 1434 upper limits (upv) (Table 1). These were used as input for the program PARADYANA [19] together with a set of 69 fixed upper limit distances. The preliminary structures were analysed using the program GLOMSA [21], modified to take NOE volumes as input, and 32 stereospecific assignments were made for diastereotopic pairs of protons or methyl groups.

The effect of spin diffusion introduces an uncertainty into the conversion of experimental data to distance constraints. This effect was simulated by complete relaxation matrix calculations based on the initial protein structures and, accordingly, a parameter was set in the program PARADYANA to loosen all distance restraints by 5\%. An average of $36 \mathrm{NOE}$ restraints per amino acid residue (16 lovs and 20 upvs) and 170 per haem residue (74 lovs and 96 upvs) was used for the final calculation (Figure 1). The distribution of the number of constraints is not uniform along the protein sequence, as haem groups attached to positions 30,54 and 68 show many long distance contacts.

\section{Quality and analysis of the structures}

The twenty structures with the lowest target function values (from $1.94 \AA^{2}$ to $2.16 \AA^{2}$, average value $2.07 \AA^{2}, 11 \%$ range from the lowest value) were selected as being representative of the solution structure of the protein. The structures superimpose with an average pairwise backbone (N-C $\left.\alpha-\mathrm{C}^{\prime}\right)$ rmsd of $0.25 \AA$ and a heavy atom rmsd of $0.99 \AA$ (Supplementary Figure S2). Thus, the backbone is very well defined and the amino acid side chains showing larger conformational variability correspond to regions with higher solvent exposure. In particular, the $\mathrm{N}$ - and the C-terminals are disordered. The statistics for this family of structures is shown in Table 1. The Ramachandran plot shows $70.4 \%$ of the residues in the most favoured regions and $29 \%$ in the additionally allowed. A total of 35 hydrogen bonds were identified in the family of 20 structures with the program MOLMOL [23], 23 of which were present in at least $50 \%$ of the structures. In order to avoid different levels of protonation of the groups involved in the redox-Bohr effect, and a concomitant broadening of the signals, the PpcA solution structure (Figure 2) was determined at $\mathrm{pH} 7.1$, which is more than one $\mathrm{pH}$ unit lower than the redox-Bohr centre $p K_{a}$ in the reduced protein [8].

\footnotetext{
${ }^{15} \mathrm{~N}$ relaxation measurements

${ }^{15} \mathrm{~N}$ NMR relaxation has been used to characterize the dynamic properties of reduced PpcA in solution. The relaxation parameters $T_{1}, T_{2}$ and $\mathrm{NOE}$ were determined at 600 and $800 \mathrm{MHz}$ (Figure 3). The relaxation data were obtained for all residues except for proline residues (positions 16, 25, 35 and
} 
62) and the two N-terminal amino acids $\mathrm{Ala}^{1}$ and $\mathrm{Asp}^{2}$. The average values for $T_{1}$ are 500 and $655 \mathrm{~ms}$ and for $T_{2}$ values are 119 and $104 \mathrm{~ms}$, at 600 and $800 \mathrm{MHz}$, respectively. The average NOE value is 0.76 at $600 \mathrm{MHz}$ and 0.81 at $800 \mathrm{MHz}$, respectively. Good correlation was observed between structure and experimental relaxation data. Most residues in regular secondary structure elements exhibit heteronuclear NOE values close to the theoretical maximum indicating high rigidity in these regions (Figure 3). The overall differences in the $T_{1}$ values are not significant. Higher variability was clearly observed in the NOE and $T_{2}$ data. High $T_{2}$ values correlate with a decrease in the NOE ratio in positions $\mathrm{Asp}^{26}, \mathrm{Gly}^{34}, \mathrm{Gly}^{36}$ and the three residues at the C-terminus (positions $\mathrm{His}^{69}, \mathrm{Lys}^{70}$ and $\mathrm{Lys}^{71}$ ), which is in agreement with motions in the ns-ps time scale. Other regions of PpcA with low or average NOE values present lower $T_{2}$ values with respect to the mean. These correspond to residues $\mathrm{His}^{17}, \mathrm{Val}^{24}$ and $\mathrm{Cys}^{27}$, indicating that these residues are affected by conformational exchange processes in the $\mu \mathrm{s}-\mathrm{ms}$ time scale.

\section{pH titration}

The $\mathrm{pH}$ titration of PpcA was carried out by ${ }^{1} \mathrm{H}-{ }^{15} \mathrm{~N}$ HSQC NMR in the $\mathrm{pH}$ range 5.5-9.5 and all ${ }^{1} \mathrm{H}$ and ${ }^{15} \mathrm{~N}$ chemical shifts of the polypeptide backbone (except for residues 1 and 2 ) and side chains were measured. To estimate the effects of $\mathrm{pH}$ changes on the PpcA solution structure, the average chemical shift differences $\left(\Delta \delta_{\text {avg }}\right)$ of each amide were calculated as described by Garret and coworkers [17]. The residues whose NH signals indicated larger differences $\left(\Delta \delta_{\text {avg }}>0.2 \mathrm{ppm}\right)$ were from $\mathrm{Lys}^{7}, \mathrm{Ala}^{8}, \mathrm{Asn}^{10}, \mathrm{Ile}^{38}$ backbone and also from $\mathrm{Asn}^{10}$ side chain (Figure 4A). These residues were mapped on the structure indicated in Figure 4B. The $\mathrm{pH}$ titration of the amide signals of Lys ${ }^{7}$, $\mathrm{Ala}^{8}, \mathrm{Asn}^{10}$ and $\mathrm{Ile}^{38}$ are indicated in Figure $4 \mathrm{C}$. The NH signals of $\mathrm{Lys}^{7}, \mathrm{Ala}^{8}, \mathrm{Asn}^{10}$ have basic $p K_{a}$ values of 7.0, 7.9 and 7.5 respectively, whereas that of $\mathrm{Ile}^{38}$ has a much more acidic $p K_{a}(5.5)$. These $p K_{a}$ values obtained from the $\mathrm{pH}$ dependence of the $\mathrm{NH}$ chemical shifts show that the $\mathrm{pH}$-linked conformational changes have different origins. 


\section{DISCUSSION}

\section{Comparison of PpcA solution structure with $\mathrm{Gsc}_{7}$ crystal structures}

In solution, the structure of the trihaem cytochrome PpcA folds in a two-strand $\beta$-sheet at the Nterminus formed by $\mathrm{Asp}^{3}-\mathrm{Leu}^{6}$ and $\mathrm{Val}^{13}$-Pro ${ }^{16}$ strands, followed by three $\alpha$-helices between residues $\mathrm{Ala}^{19}-\mathrm{Lys}^{22}, \mathrm{Lys}^{43}-\mathrm{His}^{47}$, and $\mathrm{Lys}^{52}-\mathrm{Met}^{58}$. The three bis-histidinyl haem groups are arranged in a triangular way with haems I and IV almost parallel with each other and both nearly perpendicular to haem III (Figure 2). This structure was compared with the crystal structures available for the $\mathrm{GsC}_{7}[4$, $10,11]$. The parameters describing the haem geometry of PpcA in solution along with equivalent values for $\mathrm{GSC}_{7}$ crystal structures $[4,10,11]$ and cytochrome $c_{7}$ from Desulfuromonas acetoxidans $\left(\mathrm{Dac}_{7}\right)$ [26] are presented in Table 2. With exception of the crystal structure of PpcA, for which the $\mathrm{Fe}-\mathrm{Fe}$ distances and angles between the haem planes in the PpcA crystal structure are different due to the binding of the additive deoxycholate [11], the general fold and the relative positions of the three haems are similar, with a good agreement between the consensus secondary structure elements identified in the NMR and crystal structures. The average iron-iron distances found among the crystal structures of $\mathrm{PpcB}, \mathrm{PpcC}, \mathrm{PpcD}$ and $\mathrm{PpcE}$ differ by less than $4 \%$ compared to those of $\mathrm{PpcA}$ solution structure (Table 2). Differences between the haem core in PpcA solution and crystal structures were previously anticipated from the analysis of NOE interhaem connectivities between haems III and IV. Indeed, several unexpected connectivities were observed on basis of the distances taken from PpcA crystal structure [10]. The differences between the solution and crystal structures of PpcA are not just limited to the haem core but extend beyond. In particular, significant differences are observed in the polypeptide region between $\mathrm{His}^{17}$ and Glu ${ }^{39}$ that surrounds haem I.

On the other hand, the patterns of interhaem NOE connectivities were identical to those observed for $\mathrm{PpcB}$, which has the highest sequence identity with PpcA (77\%), suggesting the same haem core arrangement for both proteins in solution. The comparison between the solution structure of PpcA and $\mathrm{PpcB}$ crystal structures (Figure 5) showed that the global rmsd values of the lowest-energy NMR structure to molecule A and molecule B of PpcB in the unit cell are $1.22 \AA$ and $1.12 \AA$ for backbone atoms, respectively. Among the four $\mathrm{PpcA}$ homologue crystal structures, significant structural differences were noted by Pokkuluri and co-workers [11], in particular, on the axial ligand orientations of haem I and the polypeptide region surrounding haem I (residues 16-40). The region around haem $\mathrm{I}$ is also where the sequences of $\mathrm{Gsc}_{7}$ homologues differ the most suggesting a functional significance. In this region, the PpcA solution structure showed a non-regular helix forming a bulge between the two helical regions comprised of residues $\mathrm{Lys}^{43}-\mathrm{His}^{47}$ and $\mathrm{Lys}^{52}-\mathrm{Met}^{58}$. This structural feature is similar to the crystal structures of $\mathrm{PpcB}$ and $\mathrm{PpcC}$ but not to those of $\mathrm{PpcD}$ and $\mathrm{PpcE}$ where a regular helix is formed in this region.

\section{Backbone dynamics}

The backbone dynamics obtained for PpcA corroborates the ordered nature of the protein, and confirms that the less defined regions of the molecule are the result of their intrinsic flexibility. The ${ }^{15} \mathrm{~N}$ NMR relaxation experiments showed that the polypeptide segment between $\mathrm{His}^{17}$ and $\mathrm{Cys}^{27}$ that surrounds haem I has a dynamic behaviour that differs from rest of the protein. Interestingly, $T_{2}$ values in this region (below the mean value) point to the participation of exchange processes in the $\mu$ s-ms time regime (Figure 3). The dynamic behaviour of this region suggested that this could be an interaction surface of PpcA with other proteins, as dynamics in this time scale have been postulated to be essential for the recognition and interaction between protein molecules [27]. In fact, the detailed thermodynamic characterization of PpcA hinted that haem I and IV might have a role in recognition of PpcA redox partners [8]. The proposed functional redox-cycle for PpcA involves two dominant microstates: a microstate in the one-electron oxidised protein with haem I oxidised while keeping the redox-Bohr centre protonated $\left(P_{1 H}\right)$ and another in the two-electron oxidised protein with haems I and IV oxidised and deprotonated redox-Bohr centre $\left(P_{14}\right)$. Since haem I is oxidised in the two functional microstates, it is most likely that the haem I region of PpcA interacts with its electron acceptor. Haem $\mathrm{IV}$, which alters its oxidation state between the one-and two-electron oxidised protein, is very likely the interaction region with the electron donor. However, in contrast with the region around haem I, no backbone dynamics effects were detected around haem IV. This behaviour is not completely unexpected as there are some examples of rigid protein recognition sites [28, 29]. The lack of 
dynamics has been suggested as a requisite for the selective sequence recognition. Structurally, haem IV is stabilized by hydrogen bonds to both propionate groups (see below), restricting the backbone dynamics around this haem. This is in line with the fact that, in the crystal structures of the entire family of $\mathrm{GSC}_{7}[11]$, the region around haem I varies significantly but that around haem IV is highly conserved, probably reflecting the higher structural rigidity in this region.

\section{Haem reduction potentials and redox interactions}

The detailed thermodynamic properties of PpcA redox centres were previously reported [8] and are summarized in Table 3. The solution structure determined in the presented work allowed addressing the structural basis for the PpcA redox properties. The haem negative reduction potentials are expected for relatively exposed $c$-type haems with bis-histidine axial coordination. The haem exposures are $231.7,215.8$, and $171.3 \AA^{2}$ for haems I, III and IV respectively, and the reduction potential values of the haem groups correlate with their solvent exposure. In fact, the more exposed haems (haem I and III) have more negative reduction potentials $(-154$ and $-138 \mathrm{mV}$, respectively) whereas the least exposed one (haem IV) has the least negative reduction potential value $(-125 \mathrm{mV})$. The higher reduction potential of the latter is also reinforced by its substantial positive environment due to the presence of several neighbouring lysine residues that stabilize the reduced state of haem IV. The haem reduction potentials are also modulated by haem-haem redox interactions [8]. The positive values obtained for these interactions suggest that they are dominated by electrostatic effects, rather than conformational changes between redox stages. This is confirmed by the fact that the highest (41 $\mathrm{mV})$ and the lowest $(16 \mathrm{mV})$ redox interaction are observed between the closest (III-IV) and furthest (I-IV) pair of haem groups.

\section{Structural close-up on PpcA redox-Bohr centre: pH-linked conformational changes}

In addition to the haem-haem redox interactions, the haem reduction potentials are modulated by the solution $\mathrm{pH}$ [8]. This is designated redox-Bohr effect by analogy with the Bohr effect in the haemoglobin [30]. The redox-Bohr interaction for haem IV is twice as high as compared to that of the other two haems (Table 3), suggesting that the redox-Bohr centre is located in the vicinity of haem IV. In fact, the redox-Bohr centre was previously assigned to haem IV propionate $13\left(\mathrm{P}_{13}{ }^{\mathrm{IV}}\right.$, according to the IUPAC Nomenclature [31]) [10, 32]. The redox-Bohr effect, as observed for PpcA, is crucial for coupling electron and proton transfer at physiological $\mathrm{pH}$. The detailed thermodynamic characterization of this trihaem cytochrome indicated that such coupling involves the two microstates $P_{1 H}$ and $P_{14}$ [8]. Thus, a fraction of the energy associated with electrons received from the donor by microstate $P_{1 H}$ is used by the protein to lower the $p K_{a}$ value of the redox-Bohr centre so that protons can be released in the periplasm at physiological $\mathrm{pH}$. This mechanism would imply structural conformational changes in the neighbourhood of the redox-Bohr centre.

The solution structure determined in this work confirms $\mathrm{P}_{13}{ }^{\mathrm{IV}}$ as the redox-Bohr centre and allowed for the first time mapping the $\mathrm{pH}$-linked conformational changes associated with the protonation/deprotonation of this centre. The backbone $\mathrm{NH}$ signals of $\mathrm{Lys}^{7}, \mathrm{Ala}^{8}, \mathrm{Asn}^{10}, \mathrm{Ile}^{38}$ and from $\mathrm{Asn}^{10}$ side chain are the most affected by the protonation/deprotonation of the redox-Bohr centre (Figure 4). Residues 7,8 and 10 are part of the $\beta$-turn segment connecting the two-strand $\beta$-sheet near haem IV, whereas $\mathrm{Ile}^{38}$ is a fully conserved residue within the family of $\mathrm{GsC}_{7}$ and protects haem I and axial $\mathrm{His}^{31}$ from solvent exposure.

The amide proton of $\mathrm{Ile}^{38}$ forms a conserved hydrogen bond with the carboxyl oxygen of $\mathrm{P}_{13}{ }^{\mathrm{I}}$ in the crystal structures of the entire family of $\mathrm{Gsc}_{7}$ [11]. This hydrogen bond is not seen in PpcA solution structure probably due to the flexibility of the propionate groups of haem I. However, at lower $\mathrm{pH}$ values, the proton chemical shift of the $\mathrm{Ile}^{38} \mathrm{NH}$ signal decreases significantly suggesting the disruption of a hydrogen bond formed between the amide proton of $\mathrm{Ile}^{38}$ and the carboxyl oxygen of $\mathrm{P}_{13}{ }^{\mathrm{I}}$ upon protonation of the latter (Figure 4C).

The $p K_{a}$ values obtained for the NH signals of $\mathrm{Lys}^{7}, \mathrm{Ala}^{8}, \mathrm{Asn}^{10}$ in this work correlate with the $p K_{a}$ value of the redox-Bohr centre (8.6) previously determined for the fully reduced and protonated protein [8], and is likely to be caused by the protonation/deprotonation of the redox-Bohr centre $\left(\mathrm{P}_{13}{ }^{\mathrm{IV}}\right)$. The differences of the $p K_{a}$ values obtained for the redox-Bohr centre and those described from the analysis of the NMR signals of $\mathrm{Lys}^{7}, \mathrm{Ala}^{8}, \mathrm{Asn}^{10}$ are expected since the former value was derived 
from the global thermodynamic analysis of the properties of the redox-centres and may reflect the combined contribution of fractional protonation of several acid-base groups [33].

Although being also part of the $\beta$-turn segment connecting the two-strand $\beta$-sheet, no significant changes on the NH backbone signal were observed for residue Lys ${ }^{9}$. The most likely explanation for this resides is the conserved hydrogen bond between the Lys ${ }^{9}$ backbone $\mathrm{NH}$ and the $\mathrm{O} 2 \mathrm{~A}$ atom of $\mathrm{P}_{17}{ }_{17}$. Indeed, $\mathrm{P}_{17}{ }^{\text {IV }}$ is exposed to surface $\left(44.1 \AA^{2}\right.$ for carboxyl oxygens) and would have nearly the same $p K_{a}$ of a free propionate group $(\sim 4.0)$. Therefore, in the $\mathrm{pH}$ range studied it remains deprotonated and forms the hydrogen bond with Lys ${ }^{9}$ backbone NH.

The pH-linked conformational changes observed in the neighbourhood of $\mathrm{P}_{13}{ }^{\mathrm{IV}}$ and the structural features around this group help to rationalize the redox-Bohr effect observed in PpcA. $\mathrm{P}_{13}{ }^{\mathrm{IV}}$ is considerably less exposed to solvent than $\mathrm{P}_{17}{ }^{\mathrm{IV}}\left(16.3 \AA^{2}\right.$ and $44.1 \AA^{2}$, respectively) and thus would be very sensitive to the conformation of the protein surroundings depending on its protonation state. Being shielded from the solvent, the protonated form is stabilized which explains the $p K_{a}$ of the redox-Bohr centre well above its expected $p K_{a}$ in free solution ( 4.0). Furthermore, in the solution structure of PpcA, carbonyl oxygen of Lys ${ }^{7}$ in the $\beta$-turn (residues 7-12) is within hydrogen bonding distance from $\mathrm{P}_{13}{ }^{\text {IV }}$ (2.6 $\AA$ between $\mathrm{O} 7$ and haem IV O1D in the lowest-energy structure). Thus, deprotonation of the propionate $\mathrm{P}_{13}{ }^{\text {IV }}$ disrupts the hydrogen bond with Lys $^{7}$ leading to structural changes in the neighbourhood as a function of $\mathrm{pH}$. This is likely to be the origin of $\mathrm{pH}$-linked conformational changes in the $\beta$-turn as the above mentioned contact is not favoured when this buried propionate is deprotonated.

\section{CONCLUSIONS}

The structure of PpcA determined in this work constitutes the first solution structure of a cytochrome from G. sulfurreducens. The polypeptide fragment formed by residues 17-27 located near haem I of PpcA was identified as the most dynamic segment by analysis of the ${ }^{15} \mathrm{~N}$ relaxation parameters obtained for the backbone. This segment may be involved in interaction with other molecules. The analysis of the chemical shift variation of the backbone and side chain amide signals with $\mathrm{pH}$ allowed mapping the $\mathrm{pH}$-linked conformational changes caused by protonation/deprotonation of the redoxBohr centre, which is now confirmed to be the haem propionate $\mathrm{P}_{13}{ }^{\mathrm{IV}}$. The redox-Bohr effect of PpcA is a crucial property that allows it to perform a concerted $\mathrm{e}^{-} / \mathrm{H}^{+}$transfer and to contribute to the proton electrochemical gradient across the bacterial cytoplasmic membrane that drives ATP synthesis. The solution structure of PpcA will be used to assist in the rational design of mutants and in the mapping of interaction sites with redox partners, an essential step towards engineering variants of Gs with increased respiratory rates and the concomitant improvement in their biotechnological applications. 


\section{ACKNOWLEDGMENTS}

We would like to acknowledge to Prof. David L. Turner for the upgraded versions of structure calculation software and Dr. Daniel F. Jana for technical support. We would also like to thank Dr. David M. Tiede (Argonne National Laboratory) for many useful discussions. We acknowledge LabRMN at FCT-UNL and Rede Nacional de RMN for access to the facilities.

\section{FUNDING}

This work was supported by Fundação para a Ciência e Tecnologia (Portugal) research grant [PTDC/QUI/70182/2006] and by Ministerio de Ciencia e Innovación (Spain) research grant [CTQ2008-0080/BQU]. L.M. was supported by Fundação para a Ciência e Tecnologia [SFRH/BD/37415/2007].

P.R.P and M.S (USA) are supported in part by the US Department of Energy's Office of Science, Biological and Environmental Research GTL program under contract [DE-AC02-06CH11357] and by the US Department of Energy, Office of Science, Office of Basic Energy Sciences under contract [DE-AC02-06CH11357].

Rede Nacional de RMN is supported with funds from Fundação para a Ciência e Tecnologia, Projecto de Re-Equipamento Científico [REDE/1517/RMN/2005], Portugal. 


\section{REFERENCES}

1 Lovley, D. R. (2003) Cleaning up with genomics: applying molecular biology to bioremediation. Nat Rev Microbiol 1, 35-44

2 Lovley, D. R. (2008) The microbe electric: conversion of organic matter to electricity. Curr Opin Biotechnol 19, 564-571

3 Methé, B. A., Nelson, K. E., Eisen, J. A., Paulsen, I. T., Nelson, W., Heidelberg, J. F, Wu, D., Wu, M., Ward, N., Beanan, M. J., Dodson, R. J., Madupu, R., Brinkac, L. M., Daugherty, S. C., DeBoy, R. T., Durkin, A. S., Gwinn, M., Kolonay, J. F., Sullivan, S. A., Haft, D. H., Selengut, J., Davidsen, T. M., Zafar, N., White, O., Tran, B., Romero, C., Forberger, H. A., Weidman, J., Khouri, H., Feldblyum, T. V., Utterback, T. R., Van Aken, S. E., Lovley, D. R. and Fraser, C. M. (2003) Genome of Geobacter sulfurreducens: metal reduction in subsurface environments. Science 302, 1967-1969

4 Pokkuluri, P. R., Londer, Y. Y., Duke, N. E., Long, W. C. and Schiffer, M. (2004) Family of cytochrome $c_{7}$-type proteins from Geobacter sulfurreducens: structure of one cytochrome $c_{7}$ at $1.45 \AA$ resolution. Biochemistry 43, 849-859

5 Ding, Y. H., Hixson, K. K., Giometti, C. S., Stanley, A., Esteve-Núñez, A., Khare, T., Tollaksen, S. L., Zhu, W., Adkins, J. N., Lipton, M. S., Smith, R. D., Mester, T. and Lovley, D. R. (2006) The proteome of dissimilatory metal-reducing microorganism Geobacter sulfurreducens under various growth conditions. Biochim Biophys Acta 1764, 1198-1206

6 Shelobolina, E. S., Coppi, M. V., Korenevsky, A. A., Didonato, L. N., Sullivan, S. A., Konishi, H., Xu, H., Leang, C., Butler, J. E., Kim, B. C. and Lovley, D. R. (2007) Importance of ctype cytochromes for U(VI) reduction by Geobacter sulfurreducens. BMC Microbiol 7, 16

7 Lloyd, J. R., Leang, C., Hodges Myerson, A. L., Coppi, M. V., Cuifo, S., Methe, B., Sandler, S. J. and Lovley, D. R. (2003) Biochemical and genetic characterization of PpcA, a periplasmic c-type cytochrome in Geobacter sulfurreducens, Biochem J 369, 153-161

8 Morgado, L., Bruix, M., Pessanha, M., Londer, Y. Y. and Salgueiro, C. A. (2010) Thermodynamic characterization of a triheme cytochrome family from Geobacter sulfurreducens reveals mechanistic and functional diversity. Biophys J 99, 293-301

9 Mahadevan, R., Bond, D. R., Butler, J. E., Esteve-Núñez, A., Coppi, M. V., Palsson, B. O., Schilling, C. H. and Lovley, D. R. (2006) Characterization of metabolism in the Fe(III)-reducing organism Geobacter sulfurreducens by constraint-based modeling. Appl Environ Microbiol 72, 15581568

10 Morgado, L., Bruix, M., Orshonsky, V., Londer, Y. Y., Duke, N. E., Yang, X., Pokkuluri, P. R., Schiffer, M. and Salgueiro, C. A. (2008) Structural insights into the modulation of the redox properties of two Geobacter sulfurreducens homologous triheme cytochromes. Biochim Biophys Acta 1777, $1157-1165$

11 Pokkuluri, P. R., Londer, Y. Y., Yang, X., Duke, N. E., Erickson, J., Orshonsky, V., Johnson, G. and Schiffer, M. (2010) Structural characterization of a family of cytochromes $c_{7}$ involved in Fe(III) respiration by Geobacter sulfurreducens. Biochim Biophys Acta 1797, 222-232

12 Fernandes, A. P., Couto, I., Morgado, L., Londer, Y. Y. and Salgueiro, C. A. (2008) Isotopic labeling of $c$-type multiheme cytochromes overexpressed in E. coli. Prot Expr Purif 59, 182-188 
13 Arslan, E., Schulz, H., Zufferey, R., Kunzler, P. and Thöny-Meyer, L. (1998) Overproduction of the Bradyrhizobium japonicum c-type cytochrome subunits of the $c b b_{3}$ oxidase in Escherichia coli. Biochem Biophys Res Commun 251, 744-747

14 Londer, Y. Y., Pokkuluri, P. R., Tiede, D. M. and Schiffer, M. (2002) Production and preliminary characterization of a recombinant triheme cytochrome $c_{7}$ from Geobacter sulfurreducens in Escherichia coli. Biochim Biophys Acta 1554, 202-211

15 Wishart, D. S., Bigam, C. G., Yao, J., Abildgaard, F., Dyson, H. J., Oldfield, E., Markley, J. L. and Sykes, B. D. (1995) ${ }^{1} \mathrm{H},{ }^{13} \mathrm{C}$ and ${ }^{15} \mathrm{~N}$ chemical shift referencing in biomolecular NMR. J Biomol NMR 6, 135-140

16 Goddard, T. D. and Kneller, D. G. (2007) Sparky 3.114. University of California, San Francisco, USA

17 Garrett, D. S., Seok, Y. J., Peterkofsky, A., Clore, G. M. and Gronenborn, A. M. (1997) Identification by NMR of the binding surface for the histidine-containing phosphocarrier protein HPr on the N-terminal domain of enzyme I of the Escherichia coli phosphotransferase system. Biochemistry 36, 4393-4398

18 Morgado, L., Paixão, V. B., Salgueiro, C. A. and Bruix, M. (2011) Backbone, side chain and heme resonance assignments of the triheme cytochrome PpcA from Geobacter sulfurreducens. Biomol NMR Assign 5, 113-116

19 Turner, D. L., Brennan, L., Chamberlin, S. G., Louro, R. O. and Xavier, A. V. (1998) Determination of solution structures of paramagnetic proteins by NMR. Eur Biophys J 27, 367-375

20 Paixão, V. B., Salgueiro, C. A., Brennan, L., Reid, G. A., Chapman, S. K. and Turner, D. L. (2008) The solution structure of a tetraheme cytochrome from Shewanella frigidimarina reveals a novel family structural motif. Biochemistry 47, 11973-11980

21 Güntert, P., Braun, W. and Wüthrich, K. (1991) Efficient computation of three-dimensional protein structures in solution from nuclear magnetic resonance data using the program DIANA and the supporting programs CALIBA, HABAS and GLOMSA. J Mol Biol 217, 517-530

22 Pettersen, E. F., Goddard, T. D., Huang, C. C., Couch, G. S., Greenblatt, D. M., Meng, E. C. and Ferrin, T. E. (2004) UCSF Chimera -a visualization system for exploratory research and analysis. J Comput Chem 25, 1605-1612

23 Koradi, R., Billeter, M. and Wuthrich, K. (1996) MOLMOL: a program for display and analysis of macromolecular structures. J Mol Graph 14, 51-55, 29-32

24 Laskowski, R. A., Rullmannn, J. A., MacArthur, M. W., Kaptein, R. and Thornton, J. M. (1996) AQUA and PROCHECK-NMR: programs for checking the quality of protein structures solved by NMR. J Biomol NMR 8, 477-486

25 Turner, D. L., Salgueiro, C. A., LeGall, J. and Xavier, A. V. (1992) Structural studies of Desulfovibrio vulgaris ferrocytochrome $c_{3}$ by two-dimensional NMR. Eur J Biochem 210, 931-936

26 Assfalg, M., Banci, L., Bertini, I., Bruschi, M., Giudici-Orticoni, M. T. and Turano, P. (1999) A proton-NMR investigation of the fully reduced cytochrome $c_{7}$ from Desulfuromonas acetoxidans. Comparison between the reduced and the oxidized forms. Eur J Biochem 266, 634-643 
27 Mandel, A. M., Akke, M. and Palmer, A. G., 3rd. (1995) Backbone dynamics of Escherichia coli ribonuclease HI: correlations with structure and function in an active enzyme. J Mol Biol 246, $144-163$

28 Pérez-Cañadillas, J. M., Guenneugues, M., Campos-Olivas, R., Santoro, J., Martinez del Pozo, A., Gavilanes, J. G., Rico, M. and Bruix, M. (2002) Backbone dynamics of the cytotoxic ribonuclease $\alpha$-sarcin by ${ }^{15} \mathrm{~N}$ NMR relaxation methods. J Biomol NMR 24, 301-316

29 Fushman, D., Cahill, S. and Cowburn, D. (1997) The main-chain dynamics of the dynamin pleckstrin homology $(\mathrm{PH})$ domain in solution: analysis of ${ }^{15} \mathrm{~N}$ relaxation with monomer/dimer equilibration. J Mol Biol 266, 173-194

30 Perutz, M. F., Wilkinson, A. J., Paoli, M. and Dodson, G. G. (1998) The stereochemical mechanism of the cooperative effects in hemoglobin revisited. Annu Rev Biophys Biomol Struct 27, $1-34$

31 Moss, G. P. (1988) Nomenclature of tetrapyrroles. Recommendations 1986 IUPAC-IUB Joint Commission on Biochemical Nomenclature (JCBN). Eur J Biochem 178, 277-328

32 Dantas, J. M., Morgado, L., Londer, Y. Y., Fernandes, A. P., Louro, R. O., Pokkuluri, P. R., Schiffer, M. and Salgueiro, C. A. (2011) Pivotal role of the strictly conserved aromatic residue F15 in the cytochrome $c_{7}$ family. J Biol Inorg Chem in press, doi:10.1007/s00775-00011-00821-00778

33 Fonseca, B. M., Saraiva, I. H., Paquete, C. M., Soares, C. M., Pacheco, I., Salgueiro, C. A. and Louro, R. O. (2009) The tetraheme cytochrome from Shewanella oneidensis MR-1 shows thermodynamic bias for functional specificity of the hemes. J Biol Inorg Chem 14, 375-385

34 Assfalg, M., Banci, L., Bertini, I., Bruschi, M. and Turano, P. (1998) $800 \mathrm{MHz}{ }^{1} \mathrm{H}$ NMR solution structure refinement of oxidized cytochrome $c_{7}$ from Desulfuromonas acetoxidans. Eur J Biochem 256, 261-270

35 Czjzek, M., Arnoux, P., Haser, R. and Shepard, W. (2001) Structure of cytochrome $c_{7}$ from Desulfuromonas acetoxidans at $1.9 \AA$ resolution. Acta Crystallogr D Biol Crystallogr 57, 670-678 


\section{TABLES}

Table 1. Summary of restraint violations and quality analysis for the final families of structures for PpcA.

\begin{tabular}{lc}
\multicolumn{2}{c}{ Parameter } \\
Type of distance restraint \\
Intra-residue \\
Sequential & 879 \\
Medium range $(2 \leq|\mathrm{i}-\mathrm{j}|<5)$ & 550 \\
Long range $(|\mathrm{i}-\mathrm{j}| \geq 5)$ & 501 \\
Total & 619 \\
& 2549 \\
Upper distance limit violations & \\
Average maximum & $0.19 \pm 0.01$ \\
Number of consistent violations $(>0.2 \AA)$ & 0 \\
Lower distance limit violations & \\
Average maximum & $0.20 \pm 0.01$ \\
Number of consistent violations $(>0.2 \AA)$ & 0 \\
& \\
Van de Waals violations & $0.17 \pm 0.01$ \\
Average maximum & 0 \\
Number of consistent violations $(>0.2 \AA)$ & \\
& \\
Ramachandran Plot $(\%)$ & \\
Most favoured regions & 70.4 \\
Additionally allowed regions & 29 \\
Generously allowed regions & 0.5 \\
Disallowed regions & 0.2 \\
Stereospecific Assignments ${ }^{b}$ & 32 \\
Precision & \\
Average pairwise rmsd backbone $(\AA)$ & $0.99 \pm 0.10$ \\
Average pairwise rmsd heavy atoms $(\AA)$ & \\
\hline
\end{tabular}

${ }^{a}$ Values obtained with PROCHECK-NMR

${ }^{\mathrm{b}}$ Analysis with GLOMSA 
Table 2. Haem geometry for Gs cytochromes $c_{7}$. The values for PpcA NMR reduced structure were obtained from the lowest-energy structure. The values for the NMR solution structure of $\mathrm{Dac}_{7}[26]$ are also included for the sake of completeness and are not discussed.

\begin{tabular}{|c|c|c|c|c|c|c|c|}
\hline & \multicolumn{2}{|l|}{ NMR } & \multicolumn{3}{|c|}{ Crystal structures $^{\mathrm{a}}$} & & NMR \\
\hline & PpcA & $\mathrm{PpcA}^{\mathrm{b}}$ & $\mathrm{PpcB}^{\mathrm{c}}$ & $\mathrm{PpcC}$ & $\mathrm{PpcD}^{\mathrm{c}}$ & Ppcl & $\mathrm{Dac}_{7}^{\mathrm{d}}$ \\
\hline \multicolumn{8}{|c|}{ Haem Fe-Fe distance $(\AA)$} \\
\hline I-III & 11.7 & 11.2 & $\begin{array}{c}11.7 \\
(11.5)\end{array}$ & 11.2 & $\begin{array}{c}11.2 \\
(11.3)\end{array}$ & & 11.9 \\
\hline I-IV & 19.0 & 20.8 & $\begin{array}{c}18.2 \\
(18.8)\end{array}$ & 18.5 & $\begin{array}{c}18.2 \\
(18.2)\end{array}$ & 18.2 & 18.9 \\
\hline III-IV & 12.6 & 12.6 & $\begin{array}{c}12.6 \\
(12.8)\end{array}$ & 12.6 & (12.6) & 12.4 & 12.5 \\
\hline \multicolumn{8}{|c|}{ Angle between haem planes $\left(^{\circ}\right)$} \\
\hline I-III & 82 & 86 & $73(72)$ & 01 & $78(76)$ & 71 & 41 \\
\hline I-IV & 27 & 35 & $20(16)$ & 18 & $25(24)$ & 22 & 11 \\
\hline III-IV & 74 & 69 & 101 & 75 & $72(70)$ & 72 & 56 \\
\hline \multicolumn{8}{|c|}{ Angle between His planes $\left(^{\circ}\right)$} \\
\hline I & 50 & 57 & $79(88)$ & 52 & $\begin{array}{l}12 \\
(3)\end{array}$ & 77 & 55 \\
\hline III & 23 & 22 & $35(36)$ & 38 & $38(22)$ & 34 & 27 \\
\hline IV & 80 & 89 & $75(81)$ & 86 & $85(84)$ & 89 & 53 \\
\hline
\end{tabular}

\footnotetext{
${ }^{\text {a }}$ The values were taken from [11].

${ }^{\mathrm{b}}$ The crystal structure of PpcA between haems I and III is altered in comparison with the other Gs cytochromes $C_{7}$ due to the presence of the additive deoxycholate used in crystallization. It should not be used for structural comparisons.

${ }^{\mathrm{c}} \mathrm{PpcB}$ and $\mathrm{PpcD}$ cytochromes present two monomers in the crystal. The values corresponding to monomer $\mathrm{B}$ are given in parentheses.

${ }^{\mathrm{d}} \mathrm{Dac}_{7}$ shares $46 \%$ sequence identity with PpcA and was extensively studied by Assfalg and coworkers [26, 34] and Czjzek and co-workers [35].
} 
Table 3. Haem reduction potentials and pairwise interactions $(\mathrm{mV})$ of the fully reduced and protonated forms of PpcA [8]. The standard errors are given in parentheses.

\begin{tabular}{|c|c|c|c|c|c|c|c|}
\hline \multicolumn{3}{|c|}{ Haem redox potentials } & \multicolumn{3}{|c|}{ Redox interactions } & \multicolumn{2}{|c|}{ Redox-Bohr interactions } \\
\hline I & III & IV & I-III & I-IV & III-IV & $\mathrm{I}-\mathrm{H}$ & IV-H \\
\hline$-154(5)$ & $-138(5)$ & $-125(5)$ & $27(2)$ & $16(3)$ & $41(3)$ & $-32(4)$ & $-31(4)-58(4)$ \\
\hline
\end{tabular}




\section{FIGURE LEGENDS}

Figure 1. Number of constraints per residue used for the calculation of the structure of PpcA. Bars are white, light grey, dark grey and black for intra residue, sequential, medium and long range restraints, respectively. Residues 30, 54 and 68 also include restraints to haems I, III and IV, respectively.

Figure 2. PpcA solution structure. (A) Overlay of the 20 lowest energy NMR structures of PpcA at $\mathrm{pH}$ 7.1. Superimposition was performed using all the heavy-atoms. The peptide chain and the haems are colored grey and black, respectively. (B) Ribbon diagram of PpcA structure. Figures were produced using MOLMOL [23].

Figure $3 .{ }^{15} \mathrm{~N}$ relaxation parameters for PpcA backbone in the reduced state. (A) longitudinal $T_{1}$ relaxation times, (B) transverse $T_{2}$ relaxation times, and (C) ${ }^{1} \mathrm{H}-{ }^{15} \mathrm{~N}$ heteronuclear NOEs. Solid straight lines represent the average $T_{1}, T_{2}$ and NOE at the respective magnetic field; open circles 800 $\mathrm{MHz}$ and closed circles $600 \mathrm{MHz}$. Secondary structure elements are shown as arrows ( $\beta$-strands) and cylinders ( $\alpha$-helices).

Figure 4. pH-linked conformational changes in PpcA. (A) Weighted average of ${ }^{1} \mathrm{H}$ and ${ }^{15} \mathrm{~N}$ chemical shifts $\left(\Delta \delta_{\text {avg }}\right)$ between $\mathrm{pH} 5.5$ and 9.5. (B) Mapping of the residues showing large $\mathrm{pH}$ dependent shifts on PpcA solution structure. Residues that are close to the haem IV are indicated in green and $\mathrm{Ile}^{38}$ that forms a conserved hydrogen bond with $\mathrm{P}_{13}{ }^{\mathrm{I}}$ carboxyl oxygen is indicated in blue. Haems groups are colored red. Dashed lines indicate hydrogen bonds. (C) $\mathrm{pH}$ titration data of the most affected PpcA amide signals. In the expansion of each ${ }^{1} \mathrm{H}-{ }^{15} \mathrm{~N}-\mathrm{HSQC}$ NMR spectrum $\mathrm{pH}$ increases from violet to pink. $\mathrm{Lys}^{7}$ and $\mathrm{Ala}^{8}$ backbone amide signals are not shown since they appear in a very crowded region of the spectra.

Figure 5. Comparison of PpcA lowest energy solution structure with PpcB crystal structure (monomers A and B). Structures were superimposed in MOLMOL [23] using backbone atoms. (A) Average rmsd between each pair of structures. Closed and open symbols represent PpcB monomers A and B, respectively. (B) PpcA solution structure versus PpcB crystal structure (monomer B). PpcA solution structure is colored light grey, and $\mathrm{PpcB}$ crystal structure is black. 


\section{FIGURES}

Figure 1

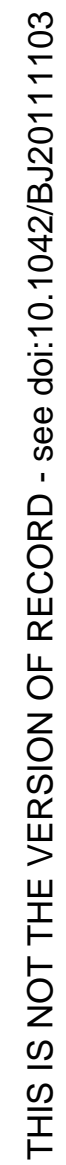

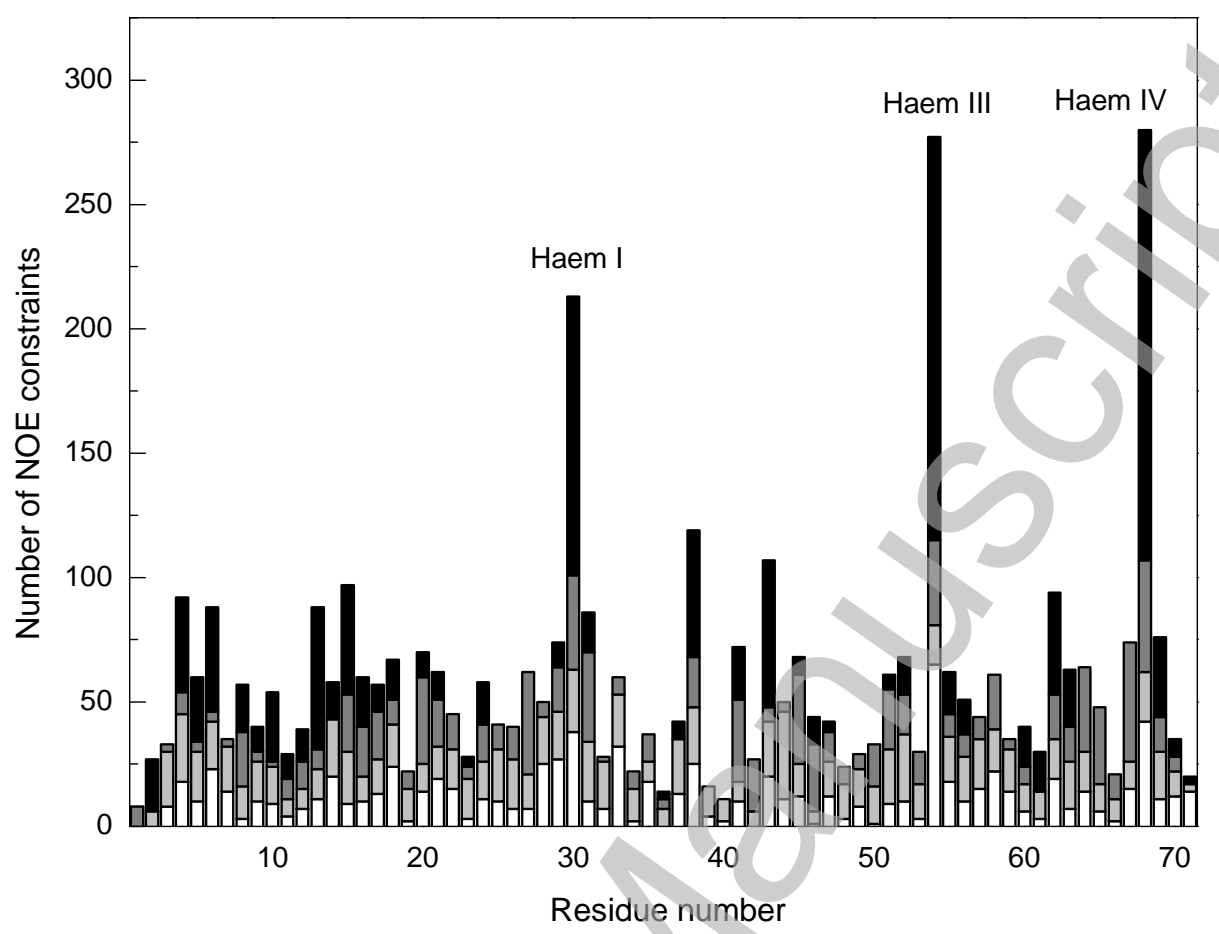


Figure 2

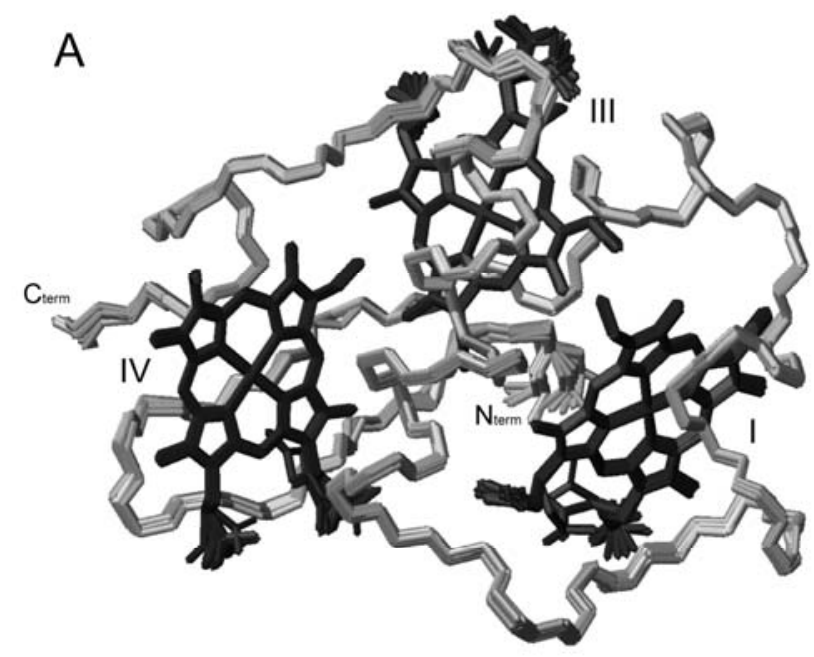

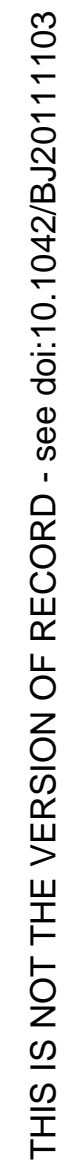

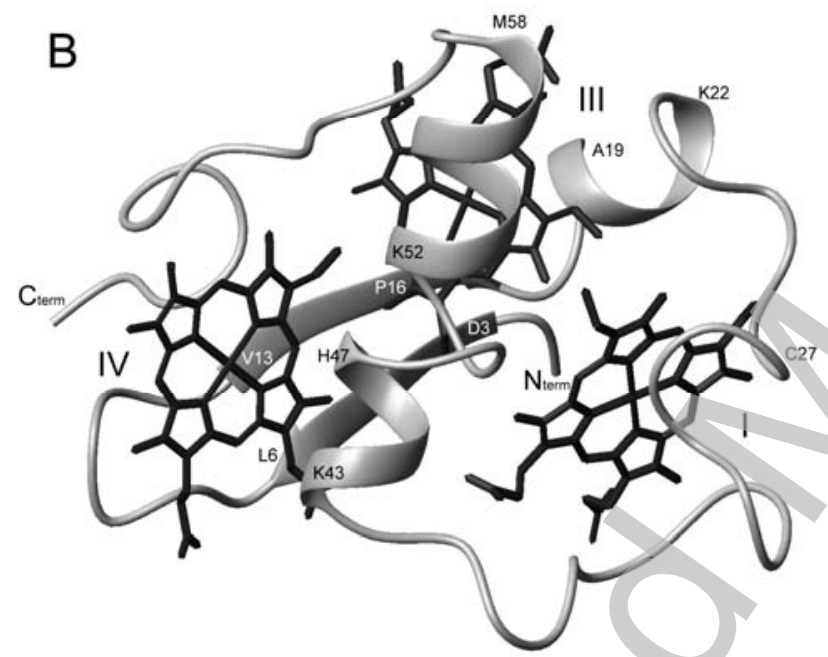

Licenced copy. Copying is not permitted, except with prior permission and as allowed by law. (C) 2011 The Authors Journal compilation (c) 2011 Portland Press Limited 


\section{Figure 3}

A

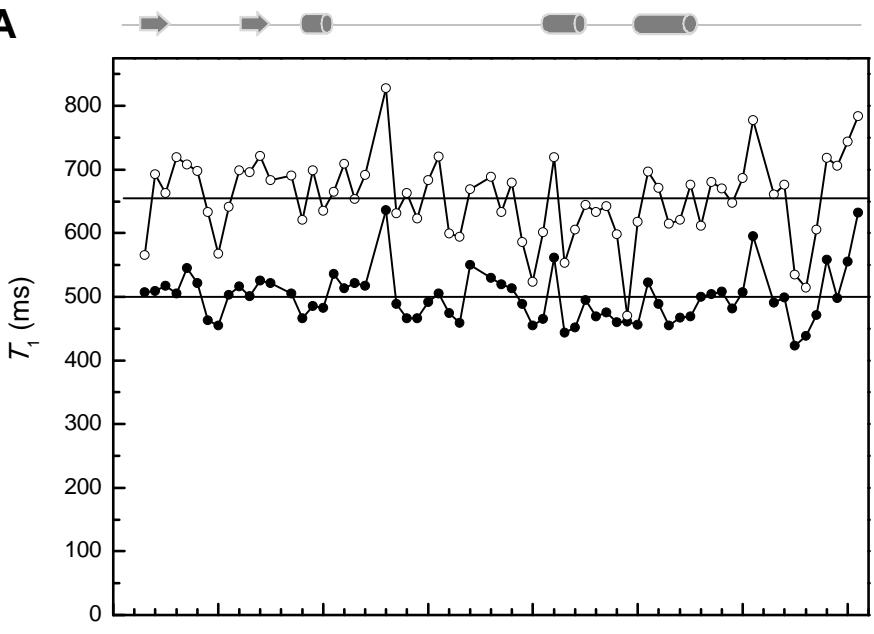

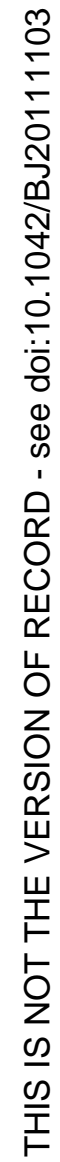

B

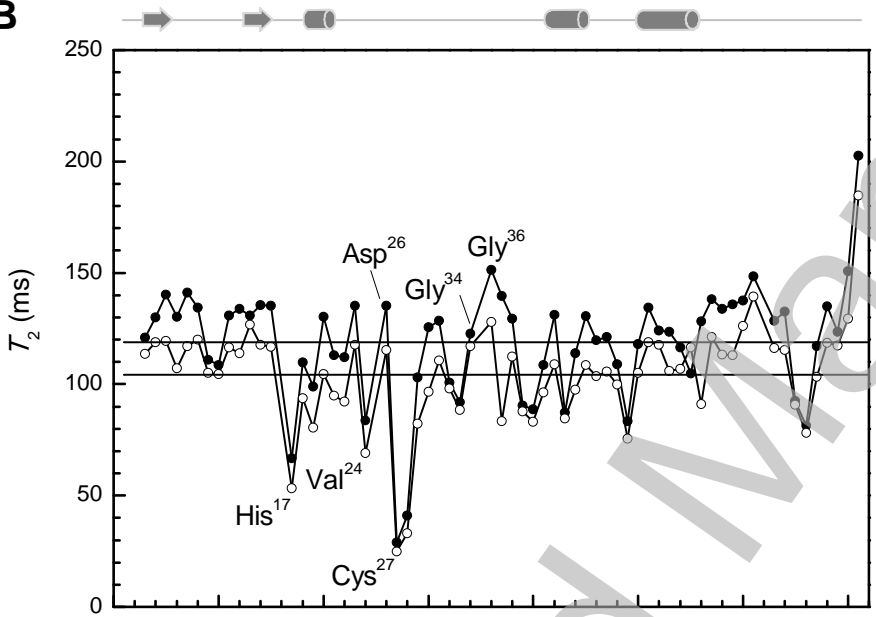

C

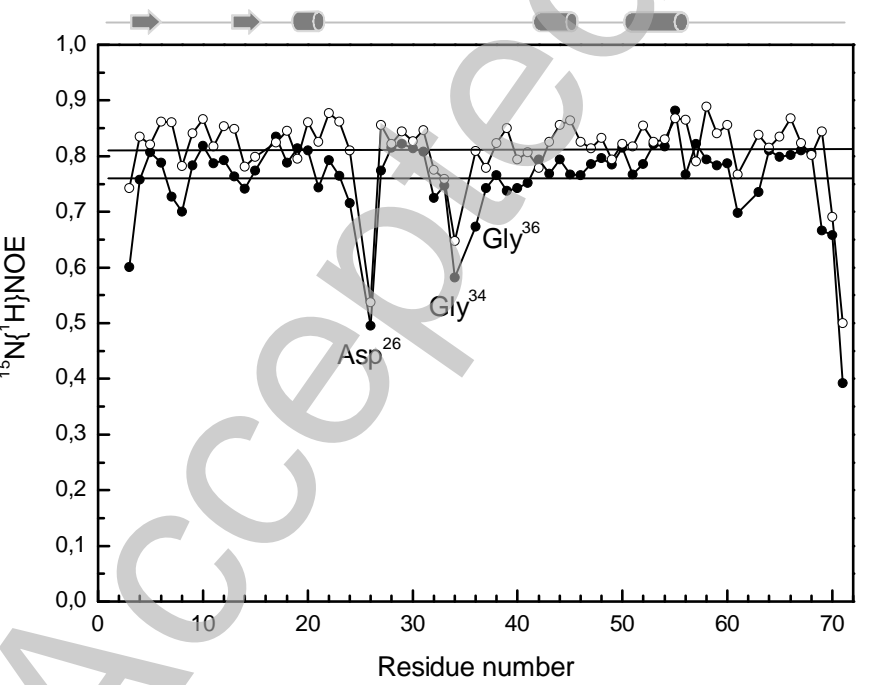


Figure 4

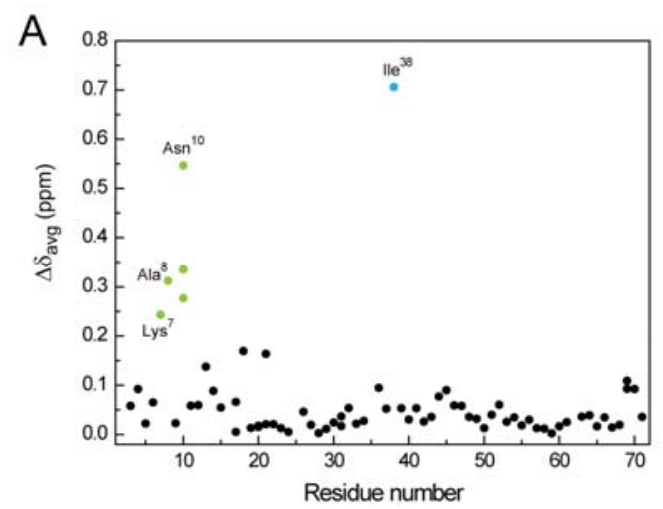

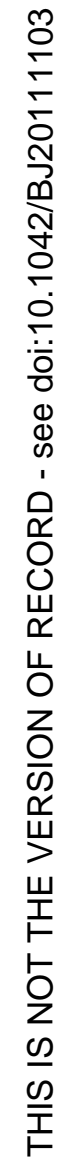
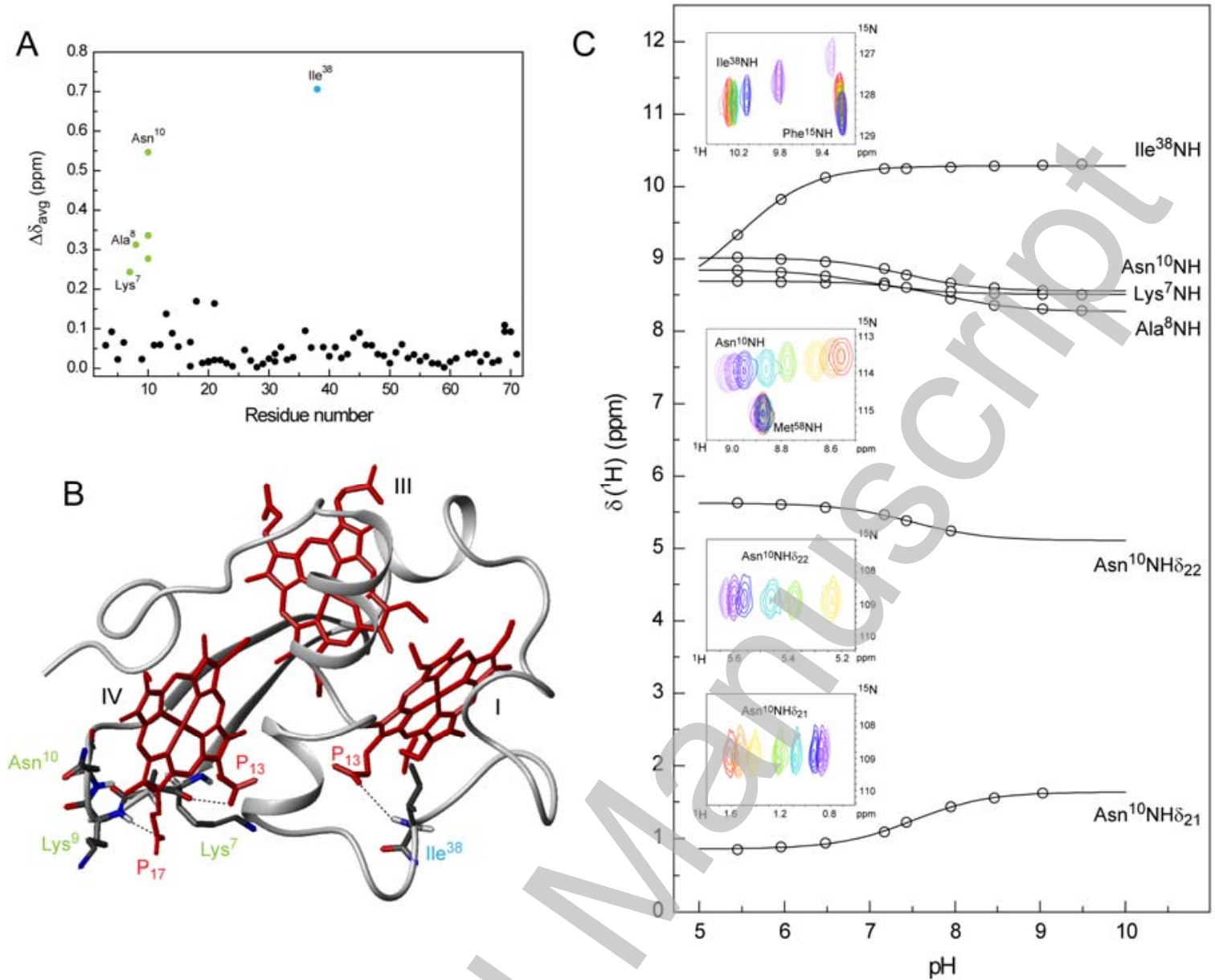

Licenced copy. Copying is not permitted, except with prior permission and as allowed by law. (c) 2011 The Authors Journal compilation (c) 2011 Portland Press Limited 


\section{Figure 5}
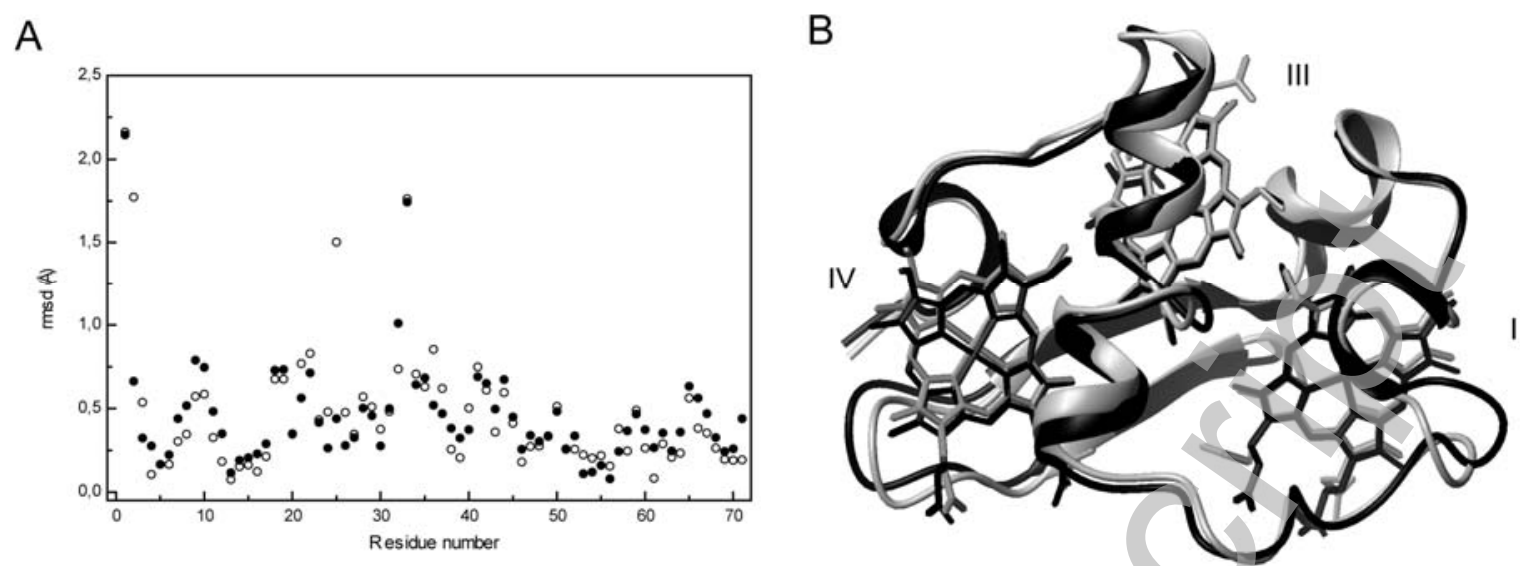